\title{
Media education role in achieving physical education goals in Poland ${ }^{1}$
}

\section{KEYWORDS}

physical education, media education, media, technology, didactics

\begin{abstract}
Magdalena Lubońska, Media education role in achieving physical education goals in Poland. Kultura - Społeczeństwo - Edukacja nr 2(20) 2021, Poznań 2021, pp. 291-300, Adam Mickiewicz University Press. ISSN 2300-0422, ISSN (Online) 2719-2717. DOI 10.14746/kse.2021.20.18
\end{abstract}

Indirect education found and is still finding its source in various media for a long time. Technological advancement results in the educators having an increased ability to use new tools in education. The goal remains the same but the social conditions impose a new identity - the subject teacher evolves into a media one. In the school system, necessary corrections have been introduced to the most important documents and the curricula, but there is still a lack of knowledge on what media education looks like in practice in specific national realities. The review article shows how goals determined by the curricula are already realized through new media in Poland and for which goals the didactic activities should be expanded. In the thematic block concerning physical activity, there is an entry: "The contents of this area have been enriched with modern forms of movement, physical activities from other European countries and use of modern technologies to monitor and plan physical activity" (MEN, 2017: 191). When organizing activities in the classroom area and with the right equipment, conducting lessons with the use of the media is not a problematic task. But are the PE teachers in a similarly comfortable position? It turns out that the development of information technology is conducive to the

\footnotetext{
* ORCID: https://orcid.org/0000-0002-8799-7696.
} 
achievement of the objectives of this subject as well. The literature review and the solutions used so far in the school system are the basis for the thesis of a correlation between the ways in which modern media are used and the formation of the students' attitudes towards physical culture.

Has everything been already discovered in the field of physical culture education? The topic of the education about the value of the body seems run out because the universality of the Znaniecki message (Znaniecki, 1973) cannot be denied. In his work, he distinguishes three educational influences: individual teaching, school teaching and an indirect social environment that complements the two previously mentioned. This indirect education found and is still finding its source in all kinds of media. Technological progress results in increased opportunities for us, educators, to use new tools in teaching. The goal remains the same, but social conditions impose a new identity - the subject teacher is transformed into a media one. "Such varying roles require the teacher to know and be able to create messages, analyze ready content, involve the media in the process of education, reflect on the media" (Kron, Sofos, 2008). As educators and policy makers adjust local curricula to reflect these technological changes, there is a lack of knowledge on how these developments have been undertaken in different national realities (Carvalho De Araújo, Knijnik, Ovens, 2020).

Changes in the new curriculum encourage delving into the ins and outs of media didactics. The thematic block on physical activity states: "The contents of this area have been enriched with modern forms of movement, physical activities from other European countries and use of modern technologies to monitor and plan physical activity" (MEN, 2017: 191). When organizing activities in the classroom area and with the right equipment, conducting lessons with the use of the media is not a problematic task. But are the PE teachers in an equally comfortable position? It turns out that the development of information technology is conducive to the achievement of the objectives of this subject as well. The literature review and the solutions used so far in the school system are the basis for the thesis of a correlation between the ways in which modern media are used and the formation of the student's attitudes towards physical culture.

Civilization changes are displayed in modern architecture of buildings. A rising number of shopping malls offers customers a resting corner where there is no shortage of sockets or charging stations. Public transport managers are also adapting to the requirements of passengers, enabling connectivity with the world 
of technology. This allows for working remotely or contacting friends without any obstacles; constantly on the Internet, constantly absorbing information coming from the media channels. Reasonable utilization of space becomes a determinant of the success of entrepreneurs. They argue that everything must be done to help the consumers realize their needs. The applied marketing strategy builds a bond between the recipient and the provider and is the basis for a sense of satisfaction with the service or product. The activities of modern educational establishments aim to achieve the same objective, despite using a different nomenclature. With the development of technology, the way of communication has changed - and this cannot be underestimated in the face of the challenges facing education in the $21^{\text {st }}$ century.

Educational activities are aimed at shaping the attitude of a person capable of self-development during and after the educational process. Therefore, the teacher's task is not only to help improve mathematical or linguistic skills, but also to adapt the student to life in the society so that in the future they can become a financially independent and beneficial part of the world. To achieve this, it is crucial to first take a thorough look at the environment to which the student is to be adopted. Computerized civilization imposes new forms of preparation of the student for life-long activity, which is evident in ministerial changes in education. The 2017 curriculum highlighted the role of media didactics using the media for "achieving pedagogically legitimate objectives" (Tulodziecki, 1997).

Media didactics is interdisciplinary (Kron, Sofos, 2008: 39), which means that every teacher, regardless of the subject, should also find fulfilment as a media teacher. In the currently promoted self-development, this trend of improving one's competences to serve the growing needs of the society is even expected. The conduct of lessons involving the media is facilitated when there is a multimedia board in the permanent equipment of the classroom. Difficulty arises in physical education classes characterized by a specific organization of space. But does this barrier eliminate the opportunity to utilize the potential of the media in the field of physical culture education? On the contrary, the successful idea of Polish pole vaulter Monika Pyrek to organize "Alternative PE Lessons" in schools perfectly illustrates that large spaces mean more possibilities. In the 2017 edition, six positions with various sport simulators were set up in the classes. Students were able to measure the speed of the ball after hitting the goal or use a photocell to check their time after a short run. The reflex measurement device that examines the speed of reaction as well as concentration caused a lot of excitement. For teachers, such a training simulator can be a tool to facilitate the 
selection of people who have a predisposition to speed sports. The classes also included the opportunity to use the Oculus Rift technology - thanks to special glasses, young people moved into the world of virtual reality. In order to defeat the co-player, it was necessary to return to traditional sports activity, which was the main goal of the "Alternative PE Lessons."

The described solution to use the media in physical education is not an isolated teaching procedure, but teachers still lack knowledge about the availability of media tools and their effectiveness in teaching. Today's physical education must be part of a broader - holistic education of students, giving them a very stable and based on sustainable values preparation for the requirements placed before them by life in dynamically developing communities and diverse socio-cultural conditions (Bronikowski, 2012). Changes in the core curriculum of physical education are the answer to students' growing. The document states that the content of education has been enriched with the use of didactic means: modern forms of physical activity, forms of physical activity originating in the region of residence of students from other European and non-European countries, as well as modern technologies for monitoring the level of physical activity (www.ore.edu.pl). The new responsibilities faced by teachers sound effusive, but there is a lack of concrete teaching guidance on how to achieve these goals. "The few Polish publications in the field of media pedagogy are still not enough in the face of growing needs, so any new position, reflecting the practice of teaching and learning in the media environment, is received with great interest" (Kron, Sofos, 2008) - I set filling this gap as an intermediate objective. Therefore, the examples of the use of information technology in physical education didactics, in the form of a list, will refer to the general requirements in the curriculum divided into five points.

\section{Shaping the ability to recognize and evaluate own physical development and physical fitness}

Bronikowski wrote that it is the dynamic development of information technology that, in the case of physical activity in the last few decades, there can be a discussion about radical behavioral changes (Bronikowski, 2015: 11). But was it not the culture of a healthy lifestyle that has created new market needs? App developers try to meet the task by writing programs that monitor physical activity. Tracking the body's measurements has become fashionable - perhaps because the media audience wants to fit themselves to the image of the perfect body 
seen on the TV screen. Awareness of a person's impact on his or her own health has also led to paying an increased attention to the body expressed in increased personal hygiene.

The popularity of mobile apps is also reflected in social networks where people logged into mobile apps share their sport achievements. A commonly used application called Endomondo allows monitoring the progress in about fifty forms of physical activity. The main page of the workout shows the duration of the effort, the speed achieved at any given time, the average speed, the distance travelled, the pace at any given time and the average pace, heart rate information, the number of calories burned, and the number of steps per minute of running. If a physical education teacher ordered students to install the Endomondo app and explain its operation, it would shape the skills acquisition which is the first of the requirements of the curriculum. Similarly, there is a www.indares.com website where teachers and students can monitor their sport achievements and compare them with other users' performance. Each recorded activity is illustrated on a graph and analyzed for energy expenditure as well as a specific "standard" of the daily dose of activity. Students are, therefore, informed whether their work toward their physical health is sufficient. This media tool allows the physical education teacher to see the activity of their students and compare their performance against other classes at the school, but above all, it informs them about the movement preferences of the users. Teachers interested in the activities attractive for the students can consider the INDARES system to be extremely useful.

Physical fitness calculator (https:/ncbkf.pl/edukacja/kalkulator/) that valuates athletic performance in relation to human ontogenetic development is also used to assess physical fitness. The modern database of the National Program for the Study of The Physical Condition of Poles (www.ncbkf.pl) collects data from physical fitness tests: Eurofit, Minifit, International Physical Fitness Test and Extra Talent. Thanks to modern technologies, knowledge on the formation of the ability to recognize and evaluate their own physical development and physical fitness can be obtained by the student outside the physical education classes, but will he or she find the motivation to extract those worthy of attention from the thicket of colorful mass media content? How can a young physical culture adept distinguish deliberations of a celebrity without any educational base from the advice of a specialist in their field? It is the task of the teacher - a guide through the world of values (Pawłucki, 1996), who, using the substantively remaining sources, indicates the direction of real development of his or her students. 


\section{Encouraging participation in recreational and sport activities}

US researchers saw the effectiveness of the media incentive when it was confirmed that after motivational text messages sent to their parents' cell phones, the number of daily child activities increased (Newton, Marker, Allen, Machtmes, Han, Johnson, Schuna, Broyles, Tudor-Locke, Church, 2014). The program lasted 12 weeks and focused on the number of steps taken. In Poland, young people can also be encouraged to physical activity through modern media. An example is the effectiveness and ever-growing popularity of The Energy Team, which is created by people well-known from the world of sport:

a) Krzysztof Golonka - sports Youtuber, World Champion of Football Tricks and finalist of Mam Talent [Poland's Got Talent];

b) Bartosz Ignacik - sports journalist and commentator, co-founder and host of the popular program "Turbokozak" on NC+;

c) Marek Citko - former footballer, 10-time Poland's representative, the person who scored the famous goal at Wembley;

d) Krzysztof Ignaczak - former volleyball player in the position of libero World Champion, Europe and six-time Poland's Champion, as well as the winner of the World League. Currently, an expert and volleyball commentator and organizer of volleyball camps for young people;

e) Izabela Bełcik - former volleyball player in the setter position. Two-time winner $(2003,2005)$ and bronze medalist (2009) of the European Championships. Seven-time Poland's champion;

f) Rafał Lipiński - the best dunker in the world, five-time FIBA $3 \times 3$ World Tour world champion.

What are the ambassadors' activities in the media? During the project, The Energy team publishes a video of the exercises on the website (www.druzynaenergii.pl) for the students who want to participate in the project. Instructions usually apply to elements of a sports game - for example, two-tact or forearm or overhand passes in the volleyball. There are also suggestions for games with the ball and performing tricks, for which physical education classes usually lack time - Krzysztof Golonka demonstrates this fun for each film, the school receives points, and the most active schools are announced as finalists of the project. In the description of the competition given in the "About the project" it reads: "From all the entries, the jury will choose the 100 most creative. Qualified schools will receive sports equipment and will fight every month for the visit of ambassadors who will conduct a unique PE lesson at the winners' school. Each school's task in the monthly 
competition will be to record as many short videos as possible, in which students perform exercises prepared by the ambassadors." The prize in the project is to equip the gym of the top three schools, and individual awards are also presented. As many as 600 schools took part in the first edition of the project - this indicates the immense potential of the media in the implementation of the second of the requirements of the curriculum.

\section{Learning and applying safety rules during physical activity}

The idea for this objective is provided by Bronikowski: "It would also be interesting for students to register their preferences in terms of free-time activity (it can be a record of the distance travelled, or a short video of playing together with their peers/family. I think these are tasks that students can handle without any problems. On the other hand, the use of this method by teachers (e.g. a recording from the playground, which is later analyzed together with the class in terms of what can and should not be done in such a playground, etc.) requires sufficiently high media and technical competences, but certainly makes the teaching process more attractive. It is important that the student's media activity is skillfully guided (through the appropriate selection of goals and tasks) by the teacher" (Bronikowski, 2015). The suggestion that the teacher's media competence could be used to make the boring safety rules of physical activity more attractive is very well-aimed, but the vast majority of teachers do not have the appropriate qualifications for this. Research on 856 future teachers showed the need to improve their competences to increase the effectiveness of media education in schools (Erdem, Erişti, 2018). Therefore, working on tools and means for teachers to improve media literacy in a systematic, modular, coherent, and research-confirmed way, is a significant challenge for didactics that needs to be taken up (Jolls, 2015).

Another indication appears in the EU guidelines on physical activity: "Community participation ('bottom-up marketing') should be involved in the activities carried out. In this respect, it seems important to use the Internet to raise public awareness or projects such as providing materials to local health institutions and schools, asking local professionals to prepare newspaper articles and engage local personalities" (EU Guidelines on Physical Activity, 2008). As with The Energy Team, media people can be crucial in shaping the attitudes of their students. If they are involved in the school's campaign on safety rules during physical activity, the probability of success of the project, i.e. the third requirement of the curriculum, will increase. 


\section{Developing skills to understand the relationship between physical activity and health and practicing health-promoting behavior}

In the $21^{\text {st }}$ century, can a person living in a media society be unaware of the link between physical activity and health? Television and magazines are teeming with images confirming the existence of this dependence. Moreover, since 1996, European health promotion networks have been set up to operate. Currently, under the name HEPA Europe, there operates a program funded by the European Union, bringing together 52 Member Organizations (EU Guidelines on Physical Activity, 2008). The conference program can be viewed at www.hepaeurope2019.org/ conference-programme-1.html - meetings are open to interested parties.

Such initiatives help the student recognize the relationship between physical activity and health. But what can be done to motivate the student to undertake pro-health activities? Hence, we touch upon the second part of the fourth requirement of the curriculum - practising health-promoting behavior. Krzysztof SasNowosielski argues that the physical environment can be a source of visual incentives "reminding" of physical activity, directing human attention to it and thus being able to increase the likelihood of undertaking it (Sas-Nowosielski, 2014). He reports that such results were achieved in a foreign experiment (Brownell, Stunkard, Albaum, 1980). Before the "elevator or stairs?" selection point, there was a sign of a beating heart, and that was enough for the number of people walking down the stairs to double within fifteen days. When the sign was removed, they just as quickly returned to the old habits. In order to change the student's attitudes for good, it is necessary to continue to promote the value of a healthy lifestyle, so that the student voluntarily begins to practice health-promoting behaviors.

\section{Shaping personal and social skills conducive to life-long physical activity}

Participation in sports competition confronts the level of the person's social skills. It happens that the students are guided by the desire to win without respecting the principles of fair play, leading to damage to the health of the coparticipants or making the competition no longer fair. The teacher of physical education should be sensitive to such situations and closely observe the behavior of the students. The thematic block on social competence includes content on the increasing the capacity to shape one's own development and to partici- 
pate autonomously and responsibly in the society, taking into consideration the ethical context of one's own conduct (MEN, 2017). Will the media prove to be a teaching aid in this case?

Bronikowski suggests that it is possible to use both sports broadcasts to draw attention to certain regulations in a given discipline, but also to use sports-themed films to show certain personality traits (Bronikowski, 2015). An example of an American series depicting moral attitudes in the face of sports competition is One Tree Hill. The coach of the school basketball team garners the universal respect of high school students thanks to the wisdom of life he offers them. Listening to a true educator, students discover the strength of the team, not of a single individual. They learn humility, fair play rules, as well as solidarity. The instruction to watch a fragment or an episode chosen by the teacher in their free time and then to analyze it together - even in the final part of the physical education lesson - has a chance to trigger the expected change.

The physical education teacher's tracking of sporting events should also take into consideration the social responsibility (CRS) theme combined with sport. Increasingly, at the Olympics or world championships, attention is drawn to the fight against racism and doping (Kuźbik, 2014). Instead, positive human relationships are promoted. When referring to current sporting events made available in the media, the teacher should use it as a trigger to discuss values and correct patterns of attitudes.

The development of civilization, in particular IT-digital technologies, forces changes in the ways of educating future generations. Meanwhile, the presence of media education dimensions in the curricula is still uneven (Rodríguez-Hoyos, Fueyo Gutiérrez, 2018). Despite the media's effectiveness in attitude formation (Scull, Kupersmidt, Weatherholt, 2017), teachers lack media competence to make full use of the media as teaching aids. An analysis of the five requirements of the curriculum confirmed that achieving the objectives of physical education through modern technologies can make the process of education in life-long physical activity, as well as the process of education in the value of the body, more attractive and effective. Influencing education through top-down requirements, although so hated by teachers, provides an opportunity to upgrade resources according to the modern needs of the students - "Thanks to political decisions, innovation is possible in schools and universities in the field of acceptance and application of new media, which can lead to a new understanding of the learning process" (Kron, Sofos, 2008).

Authors declare that there is no conflict of interest. 


\section{Bibliography}

Bronikowski M. (2012), Dydaktyka wychowania fizycznego, fizjoterapii i sportu, Poznań.

Bronikowski M. (2015), Kilka słów o nowoczesnych metodach dydaktycznych w wychowaniu fizycznym, [w:] M. Bronikowski (red.), Wychowanie fizyczne a nowoczesne technologie, Poznań, s. 9-14.

Brownell K.D., Stunkard A.J., Albaum J.M. (1980), Evaluation and Modification of Exercise Patterns in the Natural Environment, American Journal of Psychiatry, 137(12), s. 1540-1545.

Carvalho De Araújo A., Knijnik J., Ovens A.P. (2020), How Does Physical Education and Health Respond to the Growing Influence in Media and Digital Technologies? An Analysis of Curriculum in Brazil, Australia and New Zealand, Journal of Curriculum Studies, 52(1), s. 1-16, DOI: 10.1080/00220272.2020.1734664.

Erdem C., Erişti B. (2018), Paving the Way for Media Literacy Instruction in Preservice Teacher Education: Prospective Teachers' Levels of Media Literacy Skills, International Journal of Instruction, 11(4), s. 795-810.

EU Guidelines on Physical Activity (2008), Wytyczne UE dotyczące aktywności fizycznej. Zalecane działania polityczne wspierające aktywność fizyczną wpływającą pozytywnie na zdrowie. Czwarty projekt skonsolidowany, zatwierdzony przez Grupę Roboczą UE „Sport i Zdrowie”, Bruksela, https://d1dmfej9n5lgmh.cloudfront.net/msport/files/Downloads/20130103151557/ Wytyczne_UE_dotyczace_aktywnosci_fizycznej.pdf?1357226160, dostęp: 02.10.2019.

Jolls T. (2015), The New Curricula: How Media Literacy Education Transforms Teaching and Learning, Journal of Media Literacy Education, 7(1), s. 65-71.

Kron F.W., Sofos A. (2008), Dydaktyka mediów, Gdańsk.

Kuźbik P. (2014), Odpowiedzialność społeczna w sporcie, [w:] Z. Pisz, M. Rojek-Nowosielska (red.), Społeczna odpowiedzialność organizacji: diagnoza i doskonalenie, Wrocław, s. 130-140.

MEN (2017), Rozporządzenie Ministra Edukacji Narodowej z dnia 14 lutego 2017 r. w sprawie podstawy programowej wychowania przedszkolnego oraz podstawy programowej kształcenia ogólnego dla szkoły podstawowej, w tym dla uczniów z niepełnosprawnością intelektualną w stopniu umiarkowanym lub znacznym, kształcenia ogólnego dla branżowej szkoły I stopnia, kształcenia ogólnego dla szkoły specjalnej przysposabiającej do pracy oraz kształcenia ogólnego dla szkoły policealnej, DzU z 2017 r. poz. 356.

Newton R.L. Jr., Marker A.M., Allen H.R., Machtmes R., Han H., Johnson W.D., Schuna J.M. Jr., Broyles S.T., Tudor-Locke C., Church T.S. (2014), Parent-Targeted Mobile Phone Intervention to Increase Physical Activity in Sedentary Children: Randomized Pilot Trial, JMIR mHealth and uHealth, 2(4), s. e48.

Pawłucki A. (1996), Pedagogika wartości ciała, Gdańsk.

Rodríguez-Hoyos C., Fueyo Gutiérrez A. (2018), Media Training for Future Education Professionals: A Study of the Spanish Context, Digital Education Review, 33, s. 217-234.

Sas-Nowosielski K. (2014), W jaki sposób promować aktywność fizyczną wśród młodzieży? NCBKF, s. $11-15$.

Scull T.M., Kupersmidt J.B., Weatherholt T.N. (2017), The Effectiveness of Online, Family-Based Media Literacy Education for Substance Abuse Prevention in Elementary School Children: Study of the Media Detective Family Program, Journal of Community Psychology, 45(6), s. 796-809.

Tulodziecki G. (1997), Medien in Erziehung und Bildung. Grundlagen und Beispiele einer handlungs - und entwicklungsorientierten Medienpädagogik, Bad Heilbrunn/Obb.: Klinkhardt, s. 45.

Znaniecki F. (1973), Socjologia wychowania, Warszawa. 